EDUR • Educação em Revista. 2021; 37:e236284

DOI: http://dx.doi.org/10.1590/0102-4698236284

(2) (1) https://creativecommons.org/licenses/by/4.0/

ARTIGO

\title{
TRABALHO DOCENTE COM VIDEOAULAS EM EaD: DIFICULDADES DE PROFESSORES E DESAFIOS PARA A FORMAÇÃO E A PROFISSÃO DOCENTE*
}

\author{
REGINA ZANELLA PENTEADO ${ }^{1}$ \\ https://orcid.org/0000-0002-2357-9380 \\ BELARMINO CESAR GUIMARÃES DA COSTA ${ }^{2}$ \\ https://orcid.org/0000-0003-0808-8708
}

\begin{abstract}
RESUMO: O artigo aborda os impactos das tecnologias digitais no trabalho docente e na relação com a ideia de docência como profissão considerando a videoaula como principal recurso educacional da docência na EaD e no ensino remoto. O objetivo é analisar teses e dissertações brasileiras que abordam questões, problemas e dificuldades enfrentados por professores no processo de produção de videoaulas para EaD. Uma revisão no BR-CAPES-BTD resultou em 11 dissertações que mostram distanciamentos entre a formação docente e a realidade de trabalho em EaD. As precariedades envolvem aspectos de linguagens (audiovisual e do professor - expressividade) e de socialização docente. Delas decorrem efeitos prejudicantes nas dimensões: pessoalidade do professor (sentimentos negativos, desconfortos, sofrimentos e mal-estar); desenvolvimento profissional docente e impacto social da docência (qualidade do ensino). Em tempos de educação digital, a produção de videoaulas é uma prática constituinte do trabalho docente que requer ser analisada e compreendida. $\mathrm{O}$ artigo mostra uma faceta dessa realidade da docência que tensiona a profissionalização do ensino e traz novos desafios para a formação de professores.
\end{abstract}

Palavras-chave: Educação a Distância, formação de professores, trabalho docente, profissionalização docente, expressividade.

\section{TEACHING WORK WITH VIDEO CLASSES IN D.E.: DIFFICULTIES OF TEACHERS AND CHALLENGES FOR TEACHER EDUCATION AND TEACHING PROFESSION}

\begin{abstract}
The article addresses the impacts of digital technologies on teaching work and in relation to the idea of teaching as a profession considering video lessons as the main educational resource for teaching in distance education (D.E.) and remote education. The objective is to analyze Brazilian theses and dissertations that address issues, problems and difficulties faced by teachers in the process of producing video lessons for D.E. A review in BR-CAPES-BTD resulted in 11 dissertations that show distances between teacher training and the reality of work in D.E. Precariousness involves aspects of languages (audiovisual and teacher - expressiveness) and teacher socialization. These result in detrimental

\footnotetext{
${ }^{1}$ Programa de Pós-Graduação em Educação - UNESP / Rio Claro. Rio Claro, SP, Brasil. <rzpenteado@uol.com.br>

2 Programa de Pós-Graduação Educação - UNIMEP (História e Filosofia da Educação). Piracicaba, SP, Brasil.

<belarminocesar@uol.com.br>
} 
effects on the dimensions: the teacher's person (negative feelings, discomfort, sufferings and malaise); teacher professional development and social impact of teaching (teaching quality). In times of digital education, the production of video classes is a practice that is part of the teaching work that requires to be analyzed and understood. The article shows a facet of this teaching reality that stresses the professionalization of teaching and brings new challenges for teacher education.

Key-words: Distance Education, teacher education, teaching work, teaching professionalization, expressiveness.

\section{TRABAJO DOCENTE CON CLASES EN VIDEOEN EaD: DIFICULTADES Y DESAFÍOS DE PROFESORES PARA LA FORMACIÓN Y PROFESIÓN DOCENTE}

RESÚMEN: El artículo aborda los impactos de lastecnologías digitales en la labor docente y la relación con la idea de la docencia como profesión considerando las clases em video como el principal recurso educativo para la docência em educación $(\mathrm{EaD})$ a distancia y enseñanza remota. El objetivo es analizar tesis y disertaciones brasileñas que abordan cuestiones, problemas y dificultades que enfrentan los docentes en el proceso de producción de clases en video para EaD. Una revisión en BR-CAPES-BTD resultó en 11 disertaciones que muestran distancias entre la formación del profesorado y la realidade del trabajo en EaD. La precariedad involucra aspectos de los lenguajes (audiovisual y expresividad docente) y socialización docente. Estos resultan en efectos perjudiciales sobre las dimensiones: personalidade del docente (sentimientos negativos, sufrimientos y malestar); desarrollo profesional docente y impacto social de la docencia (calidad de la enseñanza). En tiempos de educación digital, la producción de clases en video es una práctica que forma parte de la labor docente en $\mathrm{EaD}$ que requiere ser analizada y comprendida. El artículo muestra una faceta de esta realidad docente que tensa la profesionalización de la docencia y trae nuevos desafíos para la formación del profesorado.

Palabras-clave: Educación a Distancia; formación de profesores; trabajo de enseñanza; profesionalización docente; expresividad.

\section{INTRODUÇÃO}

O artigo trata dos impactos das tecnologias digitais no trabalho docente na relação com a ideia de docência como profissão. O ponto de partida são questões, problemas e dificuldades enfrentados por professores no processo de produção de videoaulas para EaD.

A Educação a Distância (EaD) é uma modalidade educacional na qual a mediação didáticopedagógica nos processos de ensino e aprendizagem ocorre com a utilização de Tecnologias Digitas de Informação e Comunicação (TIDCs) com estudantes e professores desenvolvendo atividades educativas em lugares e tempos diversos e comunicação diferida. A EaD se distingue de outras formas de ensino remoto pela sua característica planejada e por exigir inovações de ordem pedagógica, didática e organizacional com metodologias, ambientes de aprendizagens, gestão e avaliação peculiares (BRASIL, 2005). A videoaula (ou teleaula ${ }^{3}$ ) é identificada pela ABED (2019) como o principal recurso educacional utilizado na docência em EaD, tanto nos cursos totalmente a distância (92,6\%) quanto nos semipresenciais $(81,8 \%)$.

\footnotetext{
${ }^{3}$ Moran (2009) identifica teleaulacomo a aula realizada a distância na qual o professor é visto pelos alunos em tempo real (síncrona); e videoaula a aula gravada e editada para posterior acesso (assíncrona). Contudo, o processo de produção é similar em ambas são realizadas em estúdio. 
A EaD, no Brasil, é considerada alternativa para democratização do acesso à educação e à inclusão social. Diversos fatores contribuíram para sua disseminação a partir de 1990: a ampliação das políticas de privatização; as inovações tecnológicas; a promulgação da Lei de Diretrizes e Bases da Educação Nacional (que regulamenta, promove, credencia e difunde a $\mathrm{EaD}$ em todos os níveis de ensino e determina que a formação de professores se daria na universidade); a expansão do Ensino Superior e a proliferação de programas de formação de professores (BRASIL, 2005; BARROS, CARVALHO, 2011; SOUZA, MOITA, CARVALHO, 2011; GATTI et al, 2019).

$\mathrm{Na}$ atualidade, o Censo EAD.BR - relatório analítico da aprendizagem a distância no Brasil, de 2018 - mostra que a EaD se consolida no cenário educacional com 2.358 .934 alunos matriculados nos diferentes níveis de ensino (ABED, 2019). Essa expansão ocorre no contexto do cenário político, econômico e educacional da crise financeira do país, com os seguintes desdobramentos: reduções dos quadros docentes em várias Instituições de Educação Superior (IES); políticas de cortes, contingenciamentos e reduções de verbas públicas para a educação; suspensão de concursos para contratação de novos professores para as IES públicas; mudanças nas formas de financiamento de ensino; fechamento de cursos e precarização do trabalho docente. Nessa conjuntura, muitos professores migram para a docência em cursos de EaD buscando oportunidades de trabalho, ainda que permeado por desafios - sem entrar, no escopo desse artigo, nas críticas às condições gerais da docência e do ensino nesta modalidade.

A atual política do governo brasileiro reforça iniciativas de ensino remoto: a Portaria $\mathrm{n}^{\circ} 2.117$, de 6/12/2019 (BRASIL, 2019) ampliou o uso do ensino remoto para os cursos presenciais de IES federais em até $40 \%$ das aulas.

No âmbito das políticas de formação docente, a Resolução no 2, de 1/07/2015 (BRASIL, 2015) dispõe que o egresso deverá possuir repertório de informações e habilidades que permita, ao professor, relacionar a linguagem dos meios de comunicação à educação, nos processos didáticopedagógicos, demonstrando domínio e uso competente das TIDCs para informação, comunicação, desenvolvimento da aprendizagem, aprimoramento da prática pedagógica e ampliação da formação cultural. Do mesmo modo, a Resolução CNE/CP no 2, de 20/12/2019 (BRASIL, 2019) consta, dentre as competências docentes: compreensão, utilização e criação de TDICs nas práticas docentes de forma crítica, significativa, reflexiva e ética, como recurso pedagógico e ferramenta de formação; bem como uso de diferentes linguagens - verbal, corporal, visual, sonora e digital; além de cuidado da própria saúde.

Cecílio e Reis (2016) consideram que o uso das TDICsdesafia a atuação dos professores, especialmente no ensino superior de EaD; e destacam a importância de estudos atentos ao mundo virtual em suas relações com o trabalho docente, a saúde e a qualidade de vida de professores. Segundo esses autores, as TDICs participam da diversificação de tarefas, do aumento da complexidade do trabalho docente, do incremento de tempo e da intensificação do trabalho; e repercutem negativamente na saúde dos professores.

Pechula e Penteado (2018) observaram que a figura do professor permanece fora do foco de investigação dos estudos sobre o trabalho de professores em EaD e realçam a importância de olhar para a prática docente em videoaulas.

No mês de março de 2020, a Organização Mundial da Saúde caracteriza como Pandemia a COVID-19 e o Ministério da Saúde do Brasil declara o status de transmissão comunitária, com orientações de isolamento social para redução da velocidade inicial da doença no país. As aulas de instituições educacionais presenciais públicas e privadas são suspensas e é autorizada a realização do ensino remoto emergencial ${ }^{4}$ (BRASIL, 2020). Na ausência de uma estratégia nacional de educação para a

\footnotetext{
${ }^{4}$ É oportuno observar a distinção entre Educação a Distância e aulas on-line de ensino remoto emergencial, este último uma medida extraordinária e solução temporária para dar seguimento às atividades de ensino em circunstâncias que impedem a realização das atividades presenciais. O ensino remoto tem como principal ferramenta a internet, sendo que as aulas (síncronas), reuniões ou videoconferências são pautadas no modelo presencial (mais personalizado e focado nas necessidades do grupo de alunos), porém de modo adaptado, virtualizado e improvisado, mediante o uso de recursos como aplicativos e plataformas que possibilitam chamadas de vídeos e encontros virtuais. Também ocorrem, eventualmente, gravações de aulas assíncronas. 
situação, os estados, os municípios e as escolas investem na busca de alternativas que possibilitem dar seguimento ao ensino e ao vínculo e diálogo entre escola/professores e alunos/famílias. Por todo o país, instituições de Educação Básica e Superior passam a organizar estratégias de adaptação dos seus cursos presenciais para o ensino remoto emergencial sendo a videoaula a principal estratégia.

Em termos de contextualização do período, cabe mencionar que diversos entraves políticos dificultaram ações estratégicas de saúde pública para o enfrentamento da Pandemia no Brasil, de modo que em cinco meses o país já contabilizava mais de 116.580 mil mortes por coronavírus, constituindo-se globalmente como segundo país com piores números, atrás dos Estados Unidos. O cenário dramático da expansão da epidemia foi agravado pela ideologização das ações políticas marcadas pelo negacionismo à ciência e pouca efetividade da gestão pública coordenada na esfera Federal. Ainda sob os desdobramentos das disputas ideológicas das eleições de 2018, período marcado pela disseminação de notícias falsas nas redes sociais, o período pandêmico ficou mais vulnerável à disseminação de informações sem embasamento técnico e científico, agora com o agravante de incidir sobre a vida das pessoas, com tratamentos e curas que não funcionam, falsidade com relação ao uso e à eficácia de medicamentos, aflorando teorias conspiratórias e discursos que minimizam a gravidade da situação.

No Brasil, o contexto pandêmico escancara a realidade dos problemas de desigualdade social e de desinvestimentos na educação pública, colocando uma lente no abismo social entre as escolas públicas e privadas e, ao mesmo tempo, explicita as diferenças entre os níveis de ensino no tocante ao perfil e às condições da comunidade docente e discente, condição que dá visibilidade às inúmeras dificuldades enfrentadas pela maioria dos estudantes e dos professores do país. Os problemas envolvem: acesso limitado à internet; tecnologias inexistentes ou obsoletas (computadores, tablets, celulares, televisores); falta de espaço apropriado para estudo e trabalho em casa; baixo aproveitamento nas aulas remotas, tanto pior quanto menor a faixa etária dos alunos; os percalços e fracassos das tentativas de viabilizar o ensino remoto na Educação Infantil e no Ensino Fundamental I. Complementam os problemas: a falta de apoio familiar aos alunos e professores; a formação frágil e o despreparo dos professores para o uso das TDICs; o despreparo e a ausência de suporte aos professores; além de sobrecarga, ansiedade, tédio, esgotamento e comprometimento da saúde mental de professores, estudantes e seus familiares.

A despeito dos problemas deflagrados, cabe considerar que as experiências de ensino desenvolvidas em tempos de medidas de isolamento social podem repercutir positivamente em possibilidades futuras de ampliação do uso das TDICs na educação. É possível antever, por exemplo, a diminuição de resistências de professores às tecnologias; a ampliação da familiaridade dos professores com o ensino mediado por tecnologias e a abertura para mudanças e inovações nas práticas de ensinoaprendizagem. Assim, para o futuro próximo, é pertinente aventar que mais professores de níveis diferentes de ensino terão experiências com videoaulas - o que poderá representar possibilidades de opções e de variações do trabalho docente em transformação, no cenário da contemporaneidade (ESTEVE, 1999 e 2014).

Na percepção de Nóvoa e Alvim (2020), a pandemia revelou a urgência e a possibilidade da transformação do modelo escolar - em poucos dias o impossível tornou-se possível: a sala de aula deu origem a uma diversidade de espaços de aprendizagem (especialmente em casa); o horário escolar tornouse volátil; os métodos de ensino em sala de aula desapareceram e surgiram diversificadas abordagens. A despeito da inconsistência e da fragilidade das respostas dos sistemas nacionais de educação, muitas escolas conseguiram implantar soluções criativas, evidenciando a importância do estabelecimento de laços de confiança entre escolas, famílias, alunos e comunidades. Além disso, cabe realçar que as melhores respostas foram dadas pelos professores, sempre que eles dispunham de autonomia profissional, capacidade de ação e uma dinâmica de colaboração. A pandemia revelou problemas pré-existentes e acelerou a necessidade de mudanças, dando destaque para a importância de professores bem preparados, com reforço do profissionalismo docente, além de bom relacionamento entre a escola e as famílias e da construção de novos ambientes educacionais.

Este artigo é um estudo de revisão que tem por objetivo analisar teses e dissertações brasileiras que abordam questões, problemas e dificuldades enfrentados por professores no processo de 
produção de videoaulas para $\mathrm{EaD}^{5}$. Primeiramente, tematiza o contexto dos movimentos de profissionalização do ensino, de universitarização da formação docente e de expansão da EaD no Brasil. Depois, enfatiza os estudos que identificam desafios do trabalho docente na produção de videoaulas para, então, apresentar o estudo de revisão (percurso metodológico e resultados).

\section{O MOVIMENTO DE PROFISSIONALIZAÇÃO DO ENSINO, A UNIVERSITARIZAÇÃO DA FORMAÇÃO DOCENTE E A EXPANSÃO DA EAD NO BRASIL}

Considera-se relevante compreender que o surgimento da EaD, no Brasil, está relacionado com a expansão do Ensino Superior e vinculado ao processo de universitarização que integra os movimentos internacionais de profissionalização docente.

O movimento de profissionalização docente, nos anos 1980 na América do Norte; anos 1990, na Europa e anos 2000, na América Latina, tem uma de suas mais fortes expressões no processo de universitarização da formação de professores (OLIVEIRA, 2010; TARDIF, 2013; MAUÉS, 2014; NÓVOA, 2017).

De um lado, o movimento pela profissionalização contribui para destacar a importância da educação para o crescimento econômico e para dar visibilidade à formação de professores e à necessidade de se construir uma base de conhecimento para o ensino - nessa perspectiva, a universitarização trouxe ganhos para o magistério, nos planos acadêmico, simbólico e científico (NÓVOA, 2009 e 2017; GATTI et al, 2019; SARTI, 2019). Contudo, por outro lado, gerou fragmentações e distanciamentos entre: a universidade e as escolas; a teoria e a prática (em detrimento das práticas e da realidade concreta das escolas e dos professores); o conhecimento universitário e a prática do trabalho docente (com os saberes, as rotinas e as culturas). Além disso, opôs: a produção acadêmica e a condição socioprofissional dos professores; a valorização dos especialistas, pesquisadores e professores universitários e a desvalorização simbólica dos professores das escolas - levando esses a perderem o seu "lugar próprio" conquistado na formação de novos professores (SARTI, 2019).

Ocorre que o projeto de profissionalização do ensino comporta ambiguidades, distorções, limitações, tensões e desafios, em que pesam as interferências que a globalização, as políticas neoliberais e os organismos internacionais acarretam nas reformas educacionais, no objeto do trabalho e nas condições da organização do trabalho docente, produzindo precarizações: alinhamento da escola à empresa e dos conteúdos às exigências do mercado em uma sociedade competitiva; educação tratada como mercadoria e vinculação dos elementos constitutivos da formação à lógica do mercado; dentre outros aspectos que intensificam o trabalho docente e corroem a autonomia e a autoridade dos professores (TARDIF, 2013; ENGUITA, 1991; OLIVEIRA, 2010; BALL et al, 2013; MAUÉS, 2014; NÓVOA, 2017).

A partir de 2003, diversos programas de EaD foram implementados para colaborar com a democratização da Educação Superior no Brasil (2015), com expansão no setor privado. Com a criação da Universidade Aberta do Brasil (UAB), em 2006, ampliou-se a oferta de educação superior pública em diferentes regiões e municípios (BRASIL, 2006).

A Política Nacional de Formação de Profissionais do Magistério da Educação Básica foi instituída pelo Decreto n ${ }^{\circ}$ 6.755, de 29 de janeiro de 2009, implica na ampliação de matrícula nos Cursos de Pedagogia e Licenciatura das Instituições Públicas de Ensino Superior e na oferta de cursos presenciais e à distância de formação inicial e continuada. Assim, no mesmo ano foi criado o Plano Nacional de Formação de Professores da Educação Básica - PARFOR, dinamizado pela Plataforma Freire, que oferece cursos abertos, presenciais e à distância.

O Censo da Educação Superior faz um comparativo entre os anos de 2008 e 2018 demonstrando a ascensão da EaD no país: o número de ingressos aumentou em 10,6\% nas graduações presenciais e triplicou a distância; e a participação percentual dos ingressantes em cursos de graduação a distância passou de 19,8\% a próximo de 40\%. Em 2018, um total de 2.358 .934 alunos se matricularam

${ }^{5}$ Observamos que o ensino remoto emergencial do contexto pandêmico não constitui o escopo deste estudo. Educação em Revista|Belo Horizonte|v.37|e236284|2021 
em cursos de $\mathrm{EaD}$, considerados os diferentes níveis de ensino e, no mesmo ano, a modalidade respondeu por $24,3 \%$ das matrículas de graduação e 50,2\% das licenciaturas - pela primeira vez na série histórica, nos cursos de formação de professores, o número de alunos matriculados em cursos EaD superou os presenciais (BRASIL, 2019).

Contrariamente ao crescimento vertiginoso da EaD no Brasil, as pesquisas sobre o trabalho docente nessa modalidade de ensino ainda caminham a passos lentos quando comparadas às de outras áreas no âmbito da Educação (VELOSO, MILL, 2019).

\section{DESAFIOS DO TRABALHO DOCENTE EM EAD E A PRODUÇÃO DE VIDEOAULAS}

A docência em EaD configura realidade desafiadora para a formação de professores, pois envolve adequação das práticas às possibilidades e aos formatos de um processo educativo midiático com produção de aulas virtuais sob uma nova dinâmica (SANTOS, 2011; BARROS, CARVALHO, 2011; SOUZA, MOITA, CARVALHO, 2011).

Nesta linha, Mill (2014) e Veloso e Mill (2018) assinalam a passagem do processo de trabalho docente de tipo "unidocente", na docência presencial, para "polidocente", na EaD". Eles identificam processo de trabalho extremamente fragmentado e organizado de forma coletiva e cooperativa: cada parte das atividades que o compõem é atribuída a um trabalhador ou equipe com docentes e não-docentes atuando de modo colaborativo, compartilhado, articulado, em consonância e interdependência. Assim, o processo de trabalho "polidocente" apresenta aspectos contraditórios que se conciliam com as características do trabalho contemporâneo na $\mathrm{EaD}$, evidenciando elementos dificultadores e perversos ligados à fragmentação do trabalho, à flexibilização e à precarização.

A videoaula é o principal recurso empregado na educação a distância (ABED, 2019); e alguns autores assinalam desafios da formação de professores e do trabalho docente em EaD.

Rodrigues, Almeida e Dal Forno (2018) analisam produções sobre formação de professores para uso das TDICs em sala de aula e identificam que a formação dos professores para a utilização desses recursos é inexistente ou precária, com priorização do caráter técnico em detrimento do pedagógico.

No âmbito da docência em EaD, Tezonin (2018) identificou que a elaboração e produção de materiais didáticos audiovisuais acarreta inseguranças e dificuldades de professores: medo de falar diante da câmera, vestuário, maquiagem, controle de tempo, consciência espacial e corporal e uso da linguagem não verbal.

Já Saldanha (2013-a e 2013-b) analisou linguagens em teleaulas observando limites e possibilidades do diálogo pedagógico. Apontou ambiguidades para a formação, ao verificar desafios com relação à transposição didática, à interação e ao processo de ensino-aprendizagem. Identificou a existência de tensão entre as promessas de formação e os riscos de semiformação que envolve a ação docente e a espetacularização do ensino, com destaque para o caráter midiático e imagético da teleaula, que superestima a linguagem visual em comparação a ação pedagógica. De maneira ambivalente, portanto, as teleaulas podem apontar para novas e criativas formas de comunicação entre professor e alunos, mas, também, restringir processos de formação à instrução e de conhecimento à informação. Isso acontece na transposição da aula expositiva tradicional para os meios de comunicação, quando o professor é tido como animador ou apresentador de conteúdos e os alunos como telespectadores, transformando a aula em produto midiático nos moldes da informação e do entretenimento. O lugar da imagem na teleaula e na mediação pedagógica a distância é problematizado: sob o ditame da imagem, ocorre uma reorganização da ação do professor, com redução de sua prática pedagógica e deslocamento da figura do professor e de sua autoridade pedagógica para o desempenho como apresentador de conteúdos. Conclui-se que o potencial formativo da teleaula requer experiência do professor com a linguagem oral e escrita que incorpore

\footnotetext{
${ }^{6} \mathrm{Na}$ EaD, a docência engloba grupo de educadores: docente-autor; docente-formador conteudista; docenteformador/aplicador; docentes-tutores virtuais e presenciais; equipe multidisciplinar; projetistas educacionais; equipe coordenadora; e equipe de apoio técnico, sendo variável a quantidade de seus membros (MILL, 2014).
} 
elementos da conversação, das narrativas e das reflexões; e que instaure, na fala, as pausas e os silêncios para promover o diálogo, a interação, a reflexão e a construção de saberes.

Pechula e Penteado (2018) focalizaram a prática docente em videoaulas e analisaram a expressividade do professor (recursos verbais, vocais e não verbais) com o propósito de ampliar a discussão sobre a complexidade das relações entre corpo, mídia e educação. Nas videoaulas as autoras identificaram o estilo expositivo restrito à apresentação de conteúdos, tendo como elemento pedagógico principal a oralidade do professor. Nos slides houve predominância da escrita, com poucos elementos de imagem, sendo o conteúdo didático o fator de alinhamento da fala do professor aos registros dos slides. Foram poucos ou mal construídos os processos expressivos, comunicacionais ou relacionais dos docentes. Houve carência de espaços interativos ou dialógicos e as poucas investidas demonstraram falta de naturalidade e de espontaneidade. O cenário único, assim como o mobiliário, remetia a espaços de oratória em cerimoniais solenes imperando a formalidade e a tradição escolar, acadêmica ou religiosa (salão nobre, anfiteatro ou igreja). A captação das imagens não ocorria em sincronia com a expressividade docente (limitada em diversos aspectos); e houve inadequações da gestualidade (por vezes ausente, restrita ou repetitiva; em outras excessiva). No plano discursivo a proposta de EaD é tida como inovadora e criativa. Porém, na prática docente em videoaulas, prevalece a ação pedagógica tradicional. Diante disso, é ressaltada a importância da investigação da expressividade do professor também na modalidade de EaD.

Por sua vez, Moura (2019) analisou o processo de produção de videoaulas na EaD com atenção para os dilemas, desafios e perspectivas em relação ao processo pedagógico. Os professores têm dificuldades: a organização e administração do tempo da aula e de utilização de slides; a adaptação com as câmeras; e sentimentos de nervosismo, ansiedade, preocupação, desconforto, indisposição e mal-estar (alguns vomitaram por fobia de câmeras filmadoras). Frente às dificuldades dos professores, os técnicos das IES ajudam com "dicas" oriundas de repertório da área de comunicação que envolve aspectos de posicionamento/movimentação no estúdio e construção de imagens mentais referentes aos alunos. Por sua vez, as IES oferecem cursos de capacitação para os docentes, com conteúdos de teatro, figurino, maquiagem, linguagem corporal, posturas, gestos e exercícios vocais - além de noções sobre equipamentos do estúdio de gravação e como se portar diante das câmeras. O desempenho e a desinibição do professor vêm sendo mais valorizados do que o domínio do conhecimento; e a linguagem audiovisual se torna um recurso didático importante. A estrutura da videoaula (ao integrar cenário, iluminação, captação por câmeras, enquadramentos, vinhetas, trilhas, dentre outros elementos) nitidamente contém semelhanças com a produção televisiva. Desta feita, o processo de midiatização da sala de aula e a reorganização do trabalho docente são problematizados, uma vez que o professor vem sendo enquadrado no papel de apresentador de televisão e o aluno na condição de telespectador.

Em um cenário educacional que aventa novas possibilidades para as práticas de ensino e encontra na videoaula o principal recurso da educação a distância, o estudo de revisão é orientado pelas seguintes perguntas: o que dizem as teses e dissertações brasileiras a respeito dos problemas e das dificuldades enfrentados por professores no trabalho docente de produção de videoaulas para EaD? O que o trabalho docente que envolve a situação de produção de videoaulas pode dizer sobre os desafios da profissionalização docente?

\section{ESTUDO DE REVISÃO}

As buscas foram realizadas junto ao Catálogo de Teses e Dissertações da Coordenação de Aperfeiçoamento de Pessoal de Nível Superior Capes - BR-CAPES-BTD em fevereiro de 2020. O BRCAPES-BTD é um banco de dados e sistema de busca bibliográfica vinculado ao Governo Federal brasileiro que reúne registros desde 1987 e faz a divulgação digital das teses e dissertações produzidas pelos programas de mestrado e doutorado reconhecidos pelo Ministério da Educação e Cultura, no Brasil, sendo que as publicações estão em língua portuguesa.

As buscas iniciais foram realizadas em fevereiro de 2020 (portanto, antes do contexto pandêmico da COVID-19) e foram orientadas pelos termos "videoaula" e "teleaula" separadamente (sem emprego de expressões booleanas). Não houve restrição de limite de tempo para a pesquisa. E, dada a 
característica do BR-CAPES-BTD ser referente aos programas de pós-graduação nacionais, houve dispensa do uso de descritor relacionado ao contexto brasileiro.

O termo "videoaula" resultou em 64 publicações (quatro de Doutorado, 30 de Mestrado Acadêmico, 28 de Mestrado Profissional e uma de curso profissionalizante), entre os anos de 2013 e 2018. Já o termo "teleaula" resultou em 12 publicações: 10 dissertações de Mestrado Acadêmico e uma tese de Doutorado, realizadas entre 1996 e 2014. No conjunto, as buscas resultaram em 76 publicações. Sobre esse montante recaiu processo de seleção envolvendo leituras dos títulos e resumos e, quando ocorreu necessidade, também do texto completo ${ }^{7}$. A seleção foi balizada por critérios de inclusão e exclusão das pesquisas, como observado a seguir:

Configuram critérios de inclusão: a pesquisa envolver professores ou futuros professores (nesse caso estudantes de licenciaturas - professores em formação) de $\mathrm{EaD}$ (independentemente do nível de educação - se ensino superior: graduação bacharelado ou licenciatura ou pós-graduação); e a pesquisa permitir, nela, identificar a abordagem de algumas condições relacionadas com processos de trabalho de produção de videoaulas e/ou de formação para o mesmo (cursos, oficinas, workshops, capacitações, treinamentos e outros). Para a inclusão, foi tomado como prioritário o fato de a pesquisa fornecer elementos de caracterização de: situações, condições, práticas, requisitos e subsídios de produção, bem como linguagens, performance, expressividade, incluindo subjetividade de professores (sentimentos, percepções e representações) e os problemas e dificuldades enfrentados por professores - dentre outros de afinidade com o objetivo deste artigo. Tais elementos favoreceram a inclusão das pesquisas mesmo que nelas não tivessem centralidade ou abordagem direta.

Configuram critérios de exclusão: publicações repetidas e aquelas cujo tratamento dado à videoaula se distancia do escopo deste artigo. Foram excluídas, por exemplo, as pesquisas que abordam a videoaula meramente com fins de: verificação de aprendizagem de alunos; avaliação do ensino a distância; estratégia e ferramenta metodológica; estudo de recepção; objeto de análise de gêneros discursivos e televisivos; veiculação de tutoriais; suporte ou produto de conteúdo da pesquisa.

Após a aplicação destes critérios de seleção, foram excluídas 65 publicações e 11 publicações foram eleitas para integrar a revisão.

As 11 publicações foram lidas integralmente e identificadas por autor(es), ano de publicação e estado da federação da IES onde a pesquisa foi desenvolvida.

A análise de conteúdo (BARDIN, 2010) das pesquisas permitiu categorizar os resultados em dois conjuntos temáticos de elementos, quais sejam: a) questões, problemas e dificuldades enfrentados por professores no trabalho docente de prática de ensino em situação de produção de videoaulas; e b) desafios para a formação docente - as necessidades, as demandas, as potencialidades e as perspectivas. Os resultados são apresentados e sintetizados em quadros.

As discussões são encaminhadas tendo como horizonte a ideia da construção da docência como profissão - que, neste artigo, não está restrita a um nível específico de ensino.

Os aportes para a análise são de autores do campo da formação e trabalho docente.

Tardif (2013) considera que a profissionalização requer o ensino passar de concepções de vocação e de ofício (atividade rotineira, técnica, prática artesanal) para de profissão - isso envolve o reconhecimento da complexidade da docência e o conhecimento dos saberes docentes, implicando que as práticas docentes envolvam ética, autonomia e a capacidade de produção de conhecimento profissional, a partir de processos reflexivos e de reconhecimento social. Para tanto, passa a ser necessária uma visão investigativa, inovadora, reflexiva, problematizadora e crítica do ato de ensinar (TARDIF, 2013; TARDIF, MOSCOSO, 2018).

A profissionalização requer o conhecimento dos saberes docentes, pois, trata-se de trabalho complexo que engloba dilemas e contradições. Os saberes da docência, oriundos da situação concreta de

\footnotetext{
${ }^{7}$ A esse respeito, cabe esclarecer que, no catálogo CAPES, geralmente as publicações encontram-se em formato de resumo e texto completo. Contudo, eventualmente algumas produções podem não estar disponíveis; nesse caso, realizou-se busca específica na web, com o título da publicação, para acesso à publicação diretamente do repositório institucional de origem do programa de pós-graduação originário da pesquisa.

Educação em Revista|Belo Horizonte|v.37|e236284|2021
} 
ensino, precisam ser objetivados, conhecidos, reconhecidos e validados pela pesquisa (GAUTHIER et al, 1998).

Para Ramalho, Nuñez e Gauthier (2004; p.10) “pensar no professor como um profissional, trabalhar na perspectiva da docência como profissão, implica reconhecê-lo como produtor de sua identidade profissional". A (re)construção da identidade do professor precisa ser pautada em argumentos teóricos fundamentados nas práticas do contexto real da docência, olhando para as dúvidas, as dificuldades, os problemas, os dilemas e as incertezas enfrentadas pelos professores nas suas rotinas de trabalho (CARDOSO, BATISTA, GRAÇA, 2016). A profissionalização docente tem, assim, um duplo aspecto: interno (profissionalidade) e externo (profissionismo), em processo dialético de construção de identidade e de reconhecimento social (RAMALHO, NUÑEZ, GAUTHIER, 2004).

O projeto de profissionalização demanda a aproximação da formação com a realidade concreta do ensino, dos professores, dos saberes e das culturas próprias da docência, sendo que, nesta aproximação, destaque deve ser dado à figura do professor experiente no papel de formador de novos professores (NÓVOA, 2009 e 2017; GATTI et al, 2019; SARTI, 2019).

\section{TRABALHO DOCENTE DE PRODUÇÃO DE VIDEOAULAS: O QUE DIZEM AS PESQUISAS DO BR-CAPES-BTD}

Este item traz os resultados da revisão das pesquisas selecionadas do BR-CAPES (análise de conteúdo) referentes ao processo de trabalho docente de produção de videoaulas; a aspectos como questões, problemas e dificuldades de professores; bem como aos efeitos prejudicantes que esses aspectos acarretam para o professor, o seu trabalho e a qualidade do ensino a distância.

A caracterização das pesquisas (identificação, objetivo e metodologia) e os resultados da análise de conteúdo - conjuntos temáticos: "questões, problemas e dificuldades dos professores" e "desafios para a formação docente" - são apresentados no quadro 1. Já o quadro 2 sintetiza o conjunto de "questões, problemas e dificuldades de professores (Q.P.D.)" por categorias dos principais temas emergentes e identifica alguns dos aspectos envolvidos; enquanto o quadro 3 sintetiza e dá relevo aos efeitos prejudicantes que este processo acarreta para o professor, o seu trabalho e a qualidade do ensino.Os quadros 1, 2 e 3 mostram que foi identificada série de questões, problemas e dificuldades enfrentados por professores na prática de ensino com videoaulas; e que estes acarretam efeitos prejudicantes sobre a qualidade do trabalho do professor e a própria identidade docente.

Quadro 1. Caracterização das pesquisas e conjuntos temáticos (questões, problemas e dificuldades dos professores/Q.P.D. e desafios para a formação docente).

\begin{tabular}{|c|c|c|c|c|}
\hline \multicolumn{3}{|c|}{ CARACTERIZAÇÃO DAS PESQUISAS } & \multicolumn{2}{|l|}{ CONJUNTOS TEMÁTICOS } \\
\hline $\begin{array}{l}\text { IDENTIFICAÇÃO } \\
\text { Autor, ano e Estado }\end{array}$ & OBJETIVO & METODOLOGIA & $\begin{array}{c}\text { QUESTÕES, PROBLEMAS E DIFICULDADES DOS } \\
\text { PROFESSORES }\end{array}$ & $\begin{array}{c}\text { DESAFIOS PARA A } \\
\text { FORMAÇÃO } \\
\text { DOCENTE }\end{array}$ \\
\hline $\begin{array}{l}\text { VASCONCELOS } \\
\qquad \begin{array}{c}\text { (2018) } \\
\text { Paraíba }\end{array}\end{array}$ & $\begin{array}{c}\text { Analisar a } \\
\text { produção e o uso } \\
\text { de videoaulas de } \\
\text { um curso de } \\
\text { Bacharelado em } \\
\text { Administração } \\
\text { Pública } \\
\text { modalidade à } \\
\text { distância. }\end{array}$ & $\begin{array}{c}\text { Pesquisa de campo } \\
\text { documental e descritiva. } \\
\text { Recurso documental e } \\
\text { entrevista } \\
\text { semiestruturada } \\
\end{array}$ & $\begin{array}{l}\text { Postura inadequada diante da câmera; ausência de sincronização } \\
\text { de conteúdos do slide em relação à explanação oral; } \\
\text { descompasso entre a exposiçãoda informação visual (slides) e a } \\
\text { informação oral (fala); gravação realizada em ambiente de } \\
\text { cenário empobrecido ou em salas de aula tradicionais, } \\
\text { escritórios ou auditórios sem recursos virtuais. } \\
\text { Diversas carências: de capacitação do docente para produção de } \\
\text { videoaulas; de integração da equipe multidisciplinar; de apoio } \\
\text { pedagógico para a produção de videoaulas; de política que } \\
\text { sistematize diretrizes institucionais para produção/uso de } \\
\text { material instrucional (videoaulas); de infraestrutura física } \\
\text { (estúdios inadequados) e de recursos humanos. } \\
\text { A produção de videoaulas configura sobrecarga e gera vivências } \\
\text { negativas e sentimentos de desamparo, desconforto, frustração, } \\
\text { desmotivação e esgotamento físico e mental dos docentes. O } \\
\text { resultado é a precarização do EaD, com processos educativos } \\
\text { limitados e fragilizados. }\end{array}$ & $\begin{array}{l}\text { A videoaula pode diminuir } \\
\text { as barreiras da relação } \\
\text { entre professor e alunos; } \\
\text { promover a humanização; } \\
\text { favorecer a comunicação e } \\
\text { a interação com os alunos } \\
\text { e facilitar a aprendizagem } \\
\text { em EaD. } \\
\text { No entanto a produção de } \\
\text { videoaulas precisa ser } \\
\text { contemplada na formação } \\
\text { inicial e continuada de } \\
\text { professores. }\end{array}$ \\
\hline
\end{tabular}




\begin{tabular}{|c|c|c|c|c|}
\hline \multicolumn{3}{|c|}{ CARACTERIZAÇÃO DAS PESQUISAS } & \multicolumn{2}{|l|}{ CONJUNTOS TEMÁTICOS } \\
\hline $\begin{array}{l}\text { IDENTIFICAÇÃO } \\
\text { Autor, ano e Estado }\end{array}$ & OBJETIVO & METODOLOGIA & $\begin{array}{l}\text { QUESTÕES, PROBLEMAS E DIFICULDADES DOS } \\
\text { PROFESSORES }\end{array}$ & $\begin{array}{l}\text { DESAFIOS PARA A } \\
\text { FORMAÇÃO } \\
\text { DOCENTE }\end{array}$ \\
\hline $\begin{array}{l}\text { MACHADO } \\
\qquad(2018) \\
\text { Rio de Janeiro }\end{array}$ & $\begin{array}{l}\text { Investigar as } \\
\text { representações } \\
\text { sociais da } \\
\text { videoaula entre } \\
\text { professores e } \\
\text { aplicar workshop } \\
\text { de treinamento } \\
\text { em videoaula }\end{array}$ & Questionário aberto & $\begin{array}{l}\text { Relativo a videoaulas, os professores demonstram: desinteresse e } \\
\text { resistência à gravação; desconhecimento da prática de } \\
\text { produção; dificuldade com a câmera; medo; vergonha; } \\
\text { artificialidade; e conflitos identitários como docente de EaD. }\end{array}$ & $\begin{array}{ll}\text { É preciso mudar as } \\
\text { representações } & \text { de } \\
\text { professores sobre as } \\
\text { videoaulas. }\end{array}$ \\
\hline $\begin{array}{c}\text { BARBOSA } \\
\text { (2018) } \\
\text { Paraná }\end{array}$ & $\begin{array}{c}\text { Compreender a } \\
\text { importância da } \\
\text { linguagem verbal } \\
\text { e não verbal e } \\
\text { como ela pode } \\
\text { favorecer a } \\
\text { comunicação na } \\
\text { teleaula. }\end{array}$ & $\begin{array}{l}\text { Qualitativa } \\
\text { Entrevista } \\
\text { Semiestruturada }\end{array}$ & $\begin{array}{l}\text { Ter sob controle aspectos da aparência e imagem e de linguagem } \\
\text { frente às câmeras, tal qual um comunicador: os movimentos, os } \\
\text { ritmos, a postura, a gesticulação, o olhar, a expressão facial, a } \\
\text { vestimenta, a voz ("comedida e ritmada"), os acessórios, a } \\
\text { maquiagem, a vestimenta com suas texturas, padronagem e } \\
\text { cores, os cabelos com sua tintura, corte e penteado, dentre } \\
\text { outros. }\end{array}$ & $\begin{array}{l}\text { A aparência, a imagem e a } \\
\text { linguagem do professor } \\
\text { (expressividade verbal e } \\
\text { não verbal) são } \\
\text { importantes na teleaula, } \\
\text { em vistas a melhorar a } \\
\text { comunicação, a interação, } \\
\text { a empatia e a } \\
\text { aprendizagem dos alunos. }\end{array}$ \\
\hline $\begin{array}{c}\text { SILVA JR } \\
\text { (2017) } \\
\text { Pernambuco }\end{array}$ & $\begin{array}{c}\text { Analisar } \\
\text { comoaportes } \\
\text { didático- } \\
\text { pedagógicos do } \\
\text { professor são } \\
\text { mobilizados nas } \\
\text { videoaulas, } \\
\text { considerando a } \\
\text { influência da } \\
\text { dinâmica do } \\
\text { ensino. } \\
\end{array}$ & \begin{tabular}{|c|} 
Qualitativa \\
Estudo de caso - \\
Entrevista com \\
professores e produtores \\
de videoaulas. \\
Observação de \\
videoaulas. \\
Questionário com \\
alunos
\end{tabular} & $\begin{array}{l}\text { Os professores têm falta de formação e desconhecimento sobre } \\
\text { produção de videoaulas e os problemas e dificuldades dizem } \\
\text { respeito a aspectos "cinematográficos": escrita de roteiros; lidar } \\
\text { com as câmeras; emprego de linguagem oral e corporal; } \\
\text { adequação entre texto, fala e imagem nos slides; negligência de } \\
\text { subsídios didáticos (interação com outros recursos, dialogismo } \\
\text { e revisão no encerramento). Há, ainda, falta de comunicação e } \\
\text { de participação do professor com equipe de pré-produção da } \\
\text { videoaula. }\end{array}$ & $\begin{array}{l}\text { Formação continuada para } \\
\text { produção de videoaulas } \\
\text { dever englobar } \\
\text { roteirização, produção de } \\
\text { slides, comunicação, } \\
\text { linguagem adequada ao } \\
\text { público alvo, linguagem } \\
\text { oral e corporal (recursos } \\
\text { verbais e não-verbais) e } \\
\text { subsídios didáticos. }\end{array}$ \\
\hline $\begin{array}{c}\text { PRIULI } \\
\text { (2017) } \\
\text { São Paulo }\end{array}$ & \begin{tabular}{|c|} 
Descrever e \\
interpretar um \\
fenômeno/ \\
experiência \\
humana de \\
transposição - \\
adaptação de aula \\
para videoaula
\end{tabular} & \begin{tabular}{|c|} 
Qualitativa \\
Relatos, questionários, \\
conversas hermenêuticas \\
Estudantes do curso de \\
letras de uma \\
universidade privada
\end{tabular} & $\begin{array}{l}\text { Estranhamento da voz gravada, pausas na fala, nervosismo, uso } \\
\text { da câmera e exposição de si; co-autoria inexistente entre } \\
\text { professores e produtores audiovisuais; reprodução de aula } \\
\text { tradicional, com empobrecimento da linguagem audiovisual e } \\
\text { da produção de sentidos. Lacunas na formação: uso da } \\
\text { linguagem audiovisual; adaptação e transposição de linguagens } \\
\text { levando em conta a interação na comunicação assíncrona. }\end{array}$ & $\begin{array}{l}\text { Revisitar o conceito de aula } \\
\text { em tempos de } \\
\text { hibridização. A formação } \\
\text { do professor precisa } \\
\text { envolver a apropriação da } \\
\text { linguagem audiovisual e } \\
\text { das TICs para as narrativas } \\
\text { e modos de se expressar } \\
\text { em videoaulas. }\end{array}$ \\
\hline $\begin{array}{c}\text { CAMPOS } \\
\text { (2017) } \\
\text { Rio de Janeiro }\end{array}$ & $\begin{array}{c}\text { Identificar fatores } \\
\text { que configuram } \\
\text { dificuldade na } \\
\text { transposição } \\
\text { didática (aulas } \\
\text { presenciais para } \\
\text { videoaulas). }\end{array}$ & \begin{tabular}{|c|} 
Qualitativa \\
Estudo de caso. Grupo \\
focal e questionário. \\
Professores de Oficina \\
de Produção de \\
Videoaulas.
\end{tabular} & $\begin{array}{l}\text { Há pouca familiaridade dos professores com a docência em EaD. } \\
\text { As dificuldades englobam: dimensionamento do tempo; } \\
\text { compromisso com a qualidade científica da informação; a } \\
\text { elaboração do roteiro da videoaula com relação entre texto e } \\
\text { ilustrações; ações diante da câmera; uso do teleprompter e } \\
\text { movimentação compatível com a fala. }\end{array}$ & $\begin{array}{l}\text { As ações de formação e de } \\
\text { desenvolvimento } \\
\text { profissional docente } \\
\text { precisam contemplar a } \\
\text { docência em EaD, as suas } \\
\text { tecnologias de ensino e os } \\
\text { efeitos nas videoaulas. }\end{array}$ \\
\hline $\begin{array}{c}\text { MEDEIROS } \\
\text { (2016) } \\
\text { Paraná }\end{array}$ & $\begin{array}{c}\text { Estudar as } \\
\text { preferências de } \\
\text { alunos e } \\
\text { professores com } \\
\text { relação a } \\
\text { videoaula para } \\
\text { identificar } \\
\text { requisitos de } \\
\text { interface para } \\
\text { ferramentas de } \\
\text { produção de } \\
\text { videoaula. }\end{array}$ & \begin{tabular}{|c} 
Quantitativa \\
Survey. \\
Questionário de múltipla \\
escolha. \\
Análise descritiva e \\
testes estatísticos. \\
Discentes e docentes \\
de cursos técnicos.
\end{tabular} & $\begin{array}{l}\text { Os professores desconhecem metodologias ou técnicas para } \\
\text { produção de videoaulas e têm dificuldade para controlar o } \\
\text { tempo, empregar recursos interativos e realizar mudanças na } \\
\text { voz que dinamizem a fala. }\end{array}$ & $\begin{array}{l}\text { A fala do professor interfere } \\
\text { na aprendizagem. Fala } \\
\text { compassada facilita o } \\
\text { entendimento. Jáa fala } \\
\text { rápida e entusiasmada, } \\
\text { com edição de imagens } \\
\text { alternadas de professor e } \\
\text { slidefavorecem } \\
\text { envolvimento. O uso da } \\
\text { voz do professor e a } \\
\text { produção de videoaulas } \\
\text { devem ser contemplados } \\
\text { na formação docente. }\end{array}$ \\
\hline $\begin{array}{l}\text { CAMARGO } \\
\qquad(2012) \\
\text { Minas Gerais }\end{array}$ & $\begin{array}{c}\text { Analisar o } \\
\text { processo de } \\
\text { capacitação de } \\
\text { professores de } \\
\text { uma universidade } \\
\text { para dominarem a } \\
\text { linguagem do }\end{array}$ & \begin{tabular}{|c|} 
Qualitativa. \\
Estudo de caso. \\
Professores em processo \\
de capacitação e \\
treinamento para a \\
gravação de videoaulas.
\end{tabular} & $\begin{array}{l}\text { Despreparo e dificuldades dos professores englobam: } \\
\text { acanhamento, tensão, frieza, desconforto, nervoso e } \\
\text { insegurança, domínio da linguagem falada (controle da voz; } \\
\text { dicção; pronúncia; concordância; fala coloquial; vícios de } \\
\text { linguagem; regionalismo; cacoetes); domínio da expressão } \\
\text { corporal (desinibição, movimentos, gestos e expressão facial } \\
\text { compatíveis com a fala); cuidados de imagem (higiene de pele, }\end{array}$ & $\begin{array}{l}\text { A formação docente deve } \\
\text { preparar o professor para } \\
\text { atuar em EaD, } \\
\text { contemplando } \\
\text { ferramentas } \\
\text { comunicacionais, } \\
\text { tecnologias de informação }\end{array}$ \\
\hline
\end{tabular}




\begin{tabular}{|c|c|c|c|c|}
\hline \multicolumn{3}{|c|}{ CARACTERIZAÇÃO DAS PESQUISAS } & \multicolumn{2}{|l|}{ CONJUNTOS TEMÁTICOS } \\
\hline $\begin{array}{l}\text { IDENTIFICAÇÃo } \\
\text { Autor, ano e Estado }\end{array}$ & OBJETIVO & METODOLOGIA & $\begin{array}{l}\text { QUESTÕES, PROBLEMAS E DIFICULDADES DOS } \\
\text { PROFESSORES }\end{array}$ & $\begin{array}{l}\text { DESAFIOS PARA A } \\
\text { FORMAÇÃO } \\
\text { DOCENTE }\end{array}$ \\
\hline Dissertação & $\begin{array}{c}\text { vídeo, } \\
\text { evidenciando as } \\
\text { dificuldades dos } \\
\text { docentes. }\end{array}$ & & $\begin{array}{l}\text { cabelo e barba, cores e estampas das roupas, saias e decotes, } \\
\text { maquiagem); domínio de conteúdo (coerência; clareza; e poder } \\
\text { de atração e persuasão); domínio da linguagem (roteiro de } \\
\text { vídeo, coloquial e acadêmica) e do uso de teleprompter. }\end{array}$ & $\begin{array}{l}\text { e linguagem (verbal e não- } \\
\text { verbal). }\end{array}$ \\
\hline $\begin{array}{c}\text { MAZZEU } \\
\text { (2012) } \\
\text { São Paulo }\end{array}$ & $\begin{array}{c}\text { Identificar, em } \\
\text { videoaulas, os } \\
\text { processos que } \\
\text { instauram diálogo } \\
\text { e estimulam } \\
\text { atitude crítica e } \\
\text { participativa dos } \\
\text { alunos. }\end{array}$ & \begin{tabular}{|c|} 
Qualitativa. \\
Estudo de caso. \\
Análise das versões de \\
roteiro da videoaula e \\
descrição reflexiva do \\
produto. Compreensão \\
do conceito de \\
linguagem audiovisual
\end{tabular} & $\begin{array}{l}\text { A produção de videoaulas que estimulem atitudes críticas, } \\
\text { participativas e dialógicas requer do professor: fala clara e direta; } \\
\text { adequação do discurso ao formato videoaula; utilização de } \\
\text { perguntas; apresentação de ideias, explicações ou proposições } \\
\text { conflitantes; pausas retóricas ou dramáticas; dramatizações de } \\
\text { temas ou conteúdos; emoção e entonação na fala. }\end{array}$ & $\begin{array}{l}\text { A EaD requer } \\
\text { entendimento de } \\
\text { videoaula como um objeto } \\
\text { complexo que demanda } \\
\text { combinação de linguagens } \\
\text { audiovisual e do professor } \\
\text { (recursos verbais e vocais). }\end{array}$ \\
\hline $\begin{array}{l}\text { MOREIRA } \\
\text { (2010) } \\
\text { São Paulo }\end{array}$ & $\begin{array}{c}\text { Realizar leitura } \\
\text { multirreferencial } \\
\text { da } \\
\text { intersubjetividade } \\
\text { entre docentes, } \\
\text { diretor de } \\
\text { teleaulas e equipe } \\
\text { técnica na } \\
\text { construção de } \\
\text { teleaulas e curso } \\
\text { de capacitação de } \\
\text { professores para } \\
\text { TV. }\end{array}$ & \begin{tabular}{|} 
Qualitativa \\
Pesquisa-ação. \\
Depoimentos e relatos \\
de ocorrências \\
oportunizadas pelo \\
encontro da prática \\
docente com o formato \\
e a técnica televisiva para \\
produção de aulas. \\
Professores e técnicos de \\
audiovisual.
\end{tabular} & $\begin{array}{l}\text { Os professores apresentam limitações técnicas para a gravação } \\
\text { das teleaulas nos padrões de linguagem televisiva, no uso das } \\
\text { câmeras, na alternância de movimentos nos planos visuais e os } \\
\text { diferentes tipos de enquadramentos e recursos didáticos } \\
\text { audiovisuais, nos ruídos comunicacionais e na gestualidade, } \\
\text { com movimentos inadequados de mãos, braços, pernas e pés, } \\
\text { usados como válvula de escape de ansiedade. As dificuldades } \\
\text { são geradoras de ansiedade com desdobramentos de ordem } \\
\text { emocional e comportamental. As dificuldades levaram, a } \\
\text { direção e a equipe técnica da IES a criar curso de preparação } \\
\text { dos professores. }\end{array}$ & $\begin{array}{l}\text { A formação docente } \\
\text { necessita refletir sobre as } \\
\text { práticas de EaD. A } \\
\text { teleaula pode ser espaço } \\
\text { de questionamentos, } \\
\text { aprendizagens e } \\
\text { desenvolvimento de } \\
\text { competências docentes e } \\
\text { novas formas de ensinar e } \\
\text { aprender com as } \\
\text { possibilidades linguagens } \\
\text { tecnologias e las } \\
\text { comunicacionais. }\end{array}$ \\
\hline $\begin{array}{l}\text { MELO } \\
(2009) \\
\text { Bahia }\end{array}$ & $\begin{array}{l}\text { Analisar a } \\
\text { construção do } \\
\text { corpo e da } \\
\text { imagem de } \\
\text { professores em } \\
\text { estúdios de } \\
\text { televisão para } \\
\text { produção de } \\
\text { teleaulas. }\end{array}$ & $\begin{array}{l}\text { Qualitativa. } \\
\text { Estudo de caso. } \\
\text { Entrevistas. } \\
\text { Professores e } \\
\text { Equipe de produção } \\
\text { (coordenação e } \\
\text { técnicos). }\end{array}$ & $\begin{array}{l}\text { Uma IES em transição do ensino presencial para a distância, } \\
\text { parametrizada pela cultura televisiva, busca a adequação e o } \\
\text { pareamento da postura do professor à de um apresentador de } \\
\text { telejornal, tornando-o uma celebridade; bem como um } \\
\text { alinhamento da teleaula a um produto televisivo a ser } \\
\text { consumido pelos alunos. } \\
\text { Esse processo produziu efeitos na vida pessoal e transformações } \\
\text { no corpo dos professores, que se mostraram abertos a } \\
\text { elaborações, modificações e adaptações voltadas para a estética } \\
\text { e o aperfeiçoamento técnico da aparência como objetos de } \\
\text { consumo, culto e espetáculo da sociedade contemporânea. As } \\
\text { transformações envolveram cuidados com vestuário, penteado, } \\
\text { pele, maquiagem, hábitos de higiene, dietas e procedimentos } \\
\text { clínicos (aplicação de botox e cirurgias plásticas). Os } \\
\text { professores estavam em busca de padrões de embelezamento, } \\
\text { estética, aperfeiçoamento e revitalização da aparência física e até } \\
\text { mesmo da voz do professor, sendo modificada por meio de } \\
\text { recursos técnicos. A motivação para as transformações foi } \\
\text { reforçada pelos alunos, que passam a tratar os professores como } \\
\text { celebridades televisivas, pedindo-lhes autógrafos e fotografias. } \\
\text { Os professores vivenciaram sentimentos de estranhamento e } \\
\text { idealização, fascínio, glamourização e espetacularização da } \\
\text { imagem. }\end{array}$ & $\begin{array}{l}\text { A EaD é um espaço de } \\
\text { constituição e criação } \\
\text { imagética-educacional } \\
\text { resultante de expressões } \\
\text { visuais da sociedade } \\
\text { contemporânea, em um } \\
\text { processo que valoriza as } \\
\text { aparências na inversão das } \\
\text { prioridades para o ensino } \\
\text { e a formação dos alunos. }\end{array}$ \\
\hline
\end{tabular}

Fonte: Autores, 2020.

Quadro 2. Principais temas emergentes - síntese dos aspectos envolvidos.

\begin{tabular}{|c|c|c|}
\hline $\begin{array}{l}\text { Q.P.D. } \\
\text { Tema }\end{array}$ & SINTESE DOS ASPECTOS ENVOLVIDOS & REFERÊNCIA \\
\hline $\begin{array}{l}\text { Linguagem } \\
\text { audiovisual }\end{array}$ & $\begin{array}{l}\text { Ausência de formação; despreparo e desconhecimento referentes a processos, discursos, } \\
\text { práticas e recursos de linguagem audiovisual empregados nas videoaulas. } \\
\text { Falta de familiaridade com ambiente de estúdio de gravação, situação de gravação e uso de } \\
\text { equipamentos, materiais e tecnologias. }\end{array}$ & $\begin{array}{c}\text { BARBOSA (2018) } \\
\text { VASCONCELOS (2018) } \\
\text { MACHADO (2018) } \\
\text { SILVA JR (2017) } \\
\text { CAMPOS (2017) } \\
\text { PRIULI (2017) } \\
\text { MEDEIROS (2016) } \\
\text { CAMARGO (2012) } \\
\text { MAZZEU (2012) } \\
\text { MOREIRA (2010) }\end{array}$ \\
\hline
\end{tabular}




\begin{tabular}{|c|c|c|}
\hline Q.P.D. & SINTESE DOS ASPECTOS ENVOLVIDOS & REFERÊNCIA \\
\hline $\begin{array}{l}\text { Linguagem } \\
\text { do professor }\end{array}$ & $\begin{array}{l}\text { Demandas de desenvolvimento da expressividade }{ }^{8} \text { (recursos verbais, vocais e não-verbais): } \\
\text { Recursos verbais e vocais (problemas de voz, fala, pronúncia, concordância, regionalismos, } \\
\text { vícios de linguagem, ruídos comunicacionais, cacoetes etc.) } \\
\text { Recursos não verbais (problemas de postura e relação com as câmeras; falta de cuidados com } \\
\text { o corpo: pele, cabelo, barba, maquiagem, vestuário). }\end{array}$ & $\begin{array}{l}\text { BARBOSA (2018) } \\
\text { MEDEIROS (2016) } \\
\text { CAMARGO (2012) } \\
\text { MAZZEU (2012) } \\
\text { MOREIRA (2010) } \\
\text { MELO (2009) }\end{array}$ \\
\hline $\begin{array}{c}\text { Integração de } \\
\text { linguagens }\end{array}$ & $\begin{array}{l}\text { Falhas na integração e sincronização de linguagens audiovisual e do professor } \\
\text { (expressividade). } \\
\text { Falhas na transposição de recursos de aula presencial para videoaula. }\end{array}$ & $\begin{array}{l}\text { VASCONCELOS (2018) } \\
\text { BARBOSA (2018) } \\
\text { SILVA JR (2017) } \\
\text { PRIULI (2017) } \\
\text { CAMPOS (2017) } \\
\text { MEDEIROS (2016) } \\
\end{array}$ \\
\hline $\begin{array}{c}\text { Socialização } \\
\text { docente }\end{array}$ & $\begin{array}{l}\text { Falta de apoio pedagógico. Falta de apoio de professores. } \\
\text { Falhas de comunicação e de interação com a equipe multidisciplinar/multiprofissional. } \\
\text { Ausência de participação e co-autoria no processo integral de produção das videoaulas. }\end{array}$ & $\begin{array}{l}\text { VASCONCELOS (2018) } \\
\text { SILVA JR (2017) } \\
\text { PRIULI (2017) } \\
\text { CAMPOS (2017) }\end{array}$ \\
\hline
\end{tabular}

Fonte: Autores, 2020.

Quadro 3. Efeitos prejudicantes para o professor, o seu trabalho e a qualidade do ensino.

\begin{tabular}{|c|c|c|}
\hline Categoria & EFEITOS PREJUDICANTES & REFERÊNCIA \\
\hline \multirow[t]{2}{*}{ Professor } & $\begin{array}{l}\text { Vivências, percepções e representações negativas. } \\
\text { Sentimentos negativos: medo, vergonha, acanhamento, estranhamento, nervosismo, artificialidade, } \\
\text { insegurança, tensão, desamparo, desconforto, frustração, desmotivação, frieza, ansiedade, } \\
\text { distúrbios emocionais e comportamentais. Sobrecarga e esgotamento físico e mental. }\end{array}$ & $\begin{array}{l}\text { VASCONCELOS (2018) } \\
\text { MACHADO (2018) } \\
\text { PRIULI (2017) } \\
\text { CAMPOS (2017) } \\
\text { CAMARGO (2012) } \\
\text { MOREIRA (2010) }\end{array}$ \\
\hline & $\begin{array}{l}\text { Corpos e a vidas de professores à mercê de transformações estéticas da imagem física como objeto } \\
\text { de consumo, cultuação, espetacularização e glamourização. }\end{array}$ & MELO (2009) \\
\hline \multirow{3}{*}{$\begin{array}{l}\text { Trabalho } \\
\text { docente }\end{array}$} & Desinteresse e resistência de professores à gravação de videoaulas. & MACHADO (2018) \\
\hline & $\begin{array}{l}\text { Reprodução da aula tradicional presencial; negligência de subsídios didáticos; ausência de dialogia } \\
\text { no processo pedagógico; empobrecimento da produção de sentidos. }\end{array}$ & $\begin{array}{c}\text { VASCONCELOS (2018) } \\
\text { SILVA JR (2017) } \\
\text { PRIULI (2017) }\end{array}$ \\
\hline & Alinhamento da videoaula a produto de cultura midiática. & MELO (2009) \\
\hline \multirow{2}{*}{$\begin{array}{c}\text { Qualidade do } \\
\text { ensino a } \\
\text { distância }\end{array}$} & Conflitos de representações identitárias de professor. & $\begin{array}{l}\text { MACHADO (2018) } \\
\text { MELO (2009) }\end{array}$ \\
\hline & $\begin{array}{l}\text { Precarização do ensino, com processos educativos limitados e fragilizados; prejuízos para a } \\
\text { aprendizagem. }\end{array}$ & $\begin{array}{c}\text { VASCONCELOS (2018) } \\
\text { SILVA JR (2017) } \\
\text { PRIULI (2017) }\end{array}$ \\
\hline
\end{tabular}

Fonte: Autores, 2020.

A quantidade de onze publicações representa número reduzido de pesquisas que abordem as dificuldades de professores na prática de ensino em situação de produção de videoaulas em EaD. A análise da distribuição temporal mostrou que a atenção dos pesquisadores brasileiros para esse recorte específico do trabalho docente é recente, manifestada em 2009 e intensificada nos anos de 2017 e 2018 (quadro 1). Veloso e Mill (2019) evidenciaram, igualmente, que apenas uma parcela ínfima das pesquisas de programas de doutorado em Educação estão voltadas para a $\mathrm{EaD}$, apesar de grande interesse pela formação docente.

O quadro 1 permite observar que todas as produções são de mestrado, sendo a maioria de mestrado acadêmico e uma de mestrado profissional (MACHADO, 2018). A ausência de teses sugere que a temática é pouco explorada em termos de consistência acadêmica, já que o doutorado propicia pesquisas com maior adensamento metodológico e aprofundamento teórico-reflexivo. Os resultados condizem com um estudo bibliométrico sobre a produção científica de teses referentes à $\mathrm{EaD}$ e ao

${ }^{8}$ Cabe esclarecer que as maneiras de expressar as questões, problemas e dificuldades difere nas publicações; contudo, a organização dos resultados que dizem respeito a elementos da expressividade responde a uma tentativa de uniformização terminológica baseada no referencial da Fonoaudiologia (BEHLAU, DRAGONE, NAGANO, 2004; KYRILLOS, 2005). 
trabalho docente nessa modalidade (VELOSO, MILL, 2019), o qual apresentou uma nuvem de palavras composta pelos títulos das produções analisadas sendo que, dentre elas não se encontram os termos videoaula ou teleaula.

Com relação à distribuição territorial das pesquisas o quadro 1 também permite observar que a maioria foi desenvolvida em IES da região Sudeste (seis), seguida do Nordeste (três) e da região Sul (duas). Não houve pesquisas nas regiões Norte e Centro-Oeste. Esses resultados acompanham a distribuição das matrículas em EaD no país (ABED, 2019), uma vez que, segundo o Censo da Educação Superior de 2017, predomina a região Sudeste com 41\%, seguida pelas regiões Sul com 23\% e Nordeste com 19\%. Considerando a extensão do Brasil e o elevado número de IES com oferta de cursos em EaD, faltam estudos para demonstrar as diferentes realidades de professores na docência com videoaulas nas várias IES pelo país. Os resultados também acompanham a distribuição geográfica brasileira da produção científica de teses identificada no estudo de Veloso e Mill (2019), com concentração nas instituições paulistas.

Referente aos aspectos metodológicos são todas pesquisas qualitativas, exceto uma (MEDEIROS, 2016). Há predomínio do estudo de caso (cinco), seguido por pesquisa documental (duas) e pesquisa-ação (duas). Entre as estratégias, prevalecem: entrevista (cinco); questionário (cinco) e documentos (duas); sendo que apenas uma ocorrência é observada para a observação, o grupo focal, o relato e a conversa hermenêutica.

Quanto às questões, problemas e dificuldades dos professores, os quadros 1 e 2 mostram que a produção de videoaulas cria novas demandas para a prática docente, pois requer do professor competências e habilidades relacionadas com: a) a utilização de aparatos tecnológicos e o trato com a linguagem audiovisual; b) o uso de si e do próprio corpo como recurso de expressão, comunicação e o desenvolvimento da expressividade verbal, vocal e não-verbal do professor; c) a transposição, integração e sincronização das linguagens audiovisual e do professor, com seus respectivos recursos. As pesquisas contribuem para o delineamento dos aspectos deficitários da formação docente quando explicitam aspectos para a formação inicial e continuada de professores, tais como: o desenvolvimento da expressividade verbal, vocal e não-verbal do professor; a linguagem audiovisual; o ensino a distância e a docência com videoaulas.

No tocante ao uso de aparatos tecnológicos e o trato com a linguagem audiovisual, falhas da formação inicial docente no tocante à educação digital vêm sendo apontadas em estudos (CECÍLIO e REIS, 2016; RODRIGUES, ALMEIDA e DAL FORNO, 2018), sendo afirmada a necessidade de atenção para esse aspecto da formação no âmbito das políticas de formação de professores (BRASIL, 2015; BRASIL, 2019). Tal precariedade formativa também é confirmada pela ABED (2019) ao identificar que a formação para docência a distância ocorre prioritariamente em serviço, mediante "treinamentos" oferecidos pelas próprias IES contratantes. A presente revisão, através do quadro 1, evidencia estratégias de algumas IES para o enfrentamento dos problemas na prática docente com produção de videoaulas: muitas delas oferecem "oficinas", "cursos", "workshops" ou "treinamentos" para os seus professores, como observado nas dissertações de Machado (2018); Camargo (2012); Moreira (2010) e Melo (2009).

Sem desmerecer a formação em serviço, a situação específica de produção de videoaulas desafia a formação docente num aspecto peculiar: geralmente, nas IES, são técnicos e comunicadores com formação em audiovisual, televisão, cinema, publicidade e propaganda que assessoram o professor. Modelos cinematográficos e televisivos tendem a orientar a produção com a lógica da cultura midiática, que segundo Costa (2002), privilegia o impacto da imagem, a fragmentação de conteúdos e a personificação. Modelos da indústria cultural são mimetizados como padrões dos formatos das produções audiovisuais, podendo estabelecer referências estéticas para a produção de videoaulas. Entretanto, de maneira ambivalente, a mediação das tecnologias no ambiente escolar pode suscitar experiências inovadoras e criativas, ressignificando as noções de distância e presencialidade, na perspectiva de Nóvoa e Alvim (2020).

A imagem do professor, portanto, torna-se objeto estetizado a ser produzido e consumido como uma celebridade midiática, já que sua identidade docente fica diluída em meio a mixagens com perfis de atores e apresentadores de programas de entretenimento e de telejornais $\mathrm{O}$ professor, equiparado a um comunicador, cuja imagem de celebridade televisiva é construída com a aplicação de conhecimentos e 
tecnologias com linguagem audiovisual, pode até atingir o ideário estético buscado pelas IES. No entanto, isso demonstra a priorização de saberes tácitos, técnicas, linguagens, recursos e práticas da cultura midiática em detrimento dos conhecimentos, das experiências, dos saberes e da cultura docente (Quadros 1 e 3).

Os quadros 1 e 2 mostram que o professor se depara com necessidades de uso de si e do próprio corpo como recurso de expressão e comunicação nas videoaulas. Apontam, contudo, que o professor não conta com uma formação profissional docente que lhe ofereça acesso a subsídios técnicos para o desenvolvimento da expressividade verbal, vocal e não-verbal. Ele deixa de ter experiências formativas de prática de ensino a distância que envolve, por exemplo, a produção de videoaulas. Nesse cenário, a presença do aporte da área de Comunicação, com a ausência da ação da área de Fonoaudiologia (educacional, não clínico-terapêutica) para desenvolvimento da expressividade do professor constitui uma das precariedades formativas que acarreta efeitos prejudicantes sobre si próprio e o trabalho docente (Quadro 3).

Weckelmann (2008) ressalta que o professor de EaD depende da comunicação clara e ágil para desenvolver habilidades comunicativas e expressivas. A importância de estudos acerca da expressividade do professor nas modalidades de ensino presencial e a distância também foi destacada por Pechula e Penteado (2018), que consideram a temática componente fundamental para a comunicabilidade do professor. As autoras sugerem que conteúdos relativos à expressividade poderiam compor disciplina a ser ministrada por fonoaudiólogo com experiência na área de voz profissional (voz do professor), a integrar o currículo da formação docente. Contudo, em nenhuma das publicações dessa revisão foi observada a referência à participação da Fonoaudiologia em processos de formação inicial ou continuada dos professores ou de assessoria para produção de videoaulas nas IES.

A expressividade, a clareza e a agilidade comunicativa do professor agregam diferenciais de qualidade a uma aula a distância; e isso aponta para campo promissor de diálogos e parcerias entre a Educação, a Comunicação e a Fonoaudiologia visando a qualificar processos de formação e de desenvolvimento profissional de professores.

Referentes à transposição, integração e sincronização das linguagens audiovisual e do professor, com seus respectivos recursos, os quadros 1 e 2 explicitam e sintetizam questões, problemas e dificuldades já identificados por Tezonin (2018) e Moura (2019).

Os quadros 1 e 3 confirmam que, frente às questões, dificuldades e problemas enfrentados na prática docente com videoaulas, os professores de EaD submetem seu próprio corpo, sua imagem e sujeitam a si e a sua prática a lógicas que interferem na construção da identidade docente e no fazer pedagógico - descaracterizando a docência, que fica comprometida em suas lógicas e culturas por assumir referências da cultura de massa. Resultados similares, que envolvem comprometimento do processo pedagógico, foram apresentados por Saldanha (2013-a e 2013-b) e Moura (2019). Tais aspectos não podem ser subestimados na análise do trabalho docente com videoaulas - principalmente quando se tem, por perspectiva, uma ótica balizada na construção da profissionalidade na docência, que envolve a identidade de professor.

O quadro 3 permite realçar os principais efeitos prejudicantes decorrentes dos problemas e dificuldades com as videoaulas, que atingem os professores (em sua pessoalidade) e a qualidade do seu trabalho e a identidade de professor (na profissionalidade docente). Figuram, dentre os efeitos que recaem na pessoa do professor: percepções, representações, vivências e sentimentos negativos que contribuem para desconfortos, frustrações, desmotivações e sobrecargas e esgotamentos físicos e psíquicos e outras formas de sofrimentos, adoecimentos e mal-estar docentes. A repercussão negativa das TDICs sobre a saúde do professor já havia sido notada por Cecílio e Reis (2016).

Nóvoa (2009 e 2017) lembra que o professor é a pessoa e que uma parte importante da pessoa é o professor, de maneira que a formação docente deve propiciar espaços de interação entre as dimensões pessoais e profissionais, uma vez que o professor produz a "sua" vida e também a "sua" profissão. Acrescenta que olhar para a pessoa do professor é particularmente relevante nos períodos de crise, de inovações e de mudanças, quando sentimentos de falta de controle e de domínio de situações e contextos de intervenção profissional configuram fontes de estresse para os professores e exigem refazer as identidades profissionais. 
Estudos internacionais sobre o mal-estar docente mostram que a docência tanto pode levar o professor ao prazer quanto ao sofrimento (PINO JUSTE, 2018). Ao abordar o mal-estar docente, Esteve (1999 e 2014) propôs matizar as suas repercussões em ampla escala que envolve, dentre outros aspectos, as condições sociais e organizacionais do trabalho docente - incluindo questões de comunicação dos professores na instituição educacional.

O problema do mal-estar, dos sofrimentos e adoecimentos de professores é uma realidade da docência como vocação e ofício que desafia a profissionalização. A dimensão do bem-estar dialoga simultaneamente com a pessoalidade do professor e com a profissionalidade docente, de modo que Penteado e Souza Neto (2019) propõem pensar o corpo, a saúde e o bem-estar como elementos da cultura docente que substanciam o desenvolvimento profissional e a profissionalização docente. A questão do bem-estar, do cuidado e da promoção da saúde do professor deve ser tematizada na formação e na profissão docente, com o propósito de uma mudança. Ao considerar as dificuldades dos professores com a situação de produção de videoaulas, identificamos a necessidade de atenção para esse recorte da prática docente em futuras pesquisas interdisciplinares preocupadas com as relações entre trabalho e saúde de professores. Nesse sentido, o cuidado com a saúde física e mental figura dentre as competências docentes na atual política de formação (BRASIL, 2019).

Já outros efeitos extrapolam a pessoalidade do professor e atingem a profissionalidade da docência, como a atribuição de novos papéis e a (re)construção de identidade docente - aspectos identificados nos estudos de Machado (2018) e Melo (2009).

Desta feita, cabe observar que, tanto as questões, as dificuldades e os problemas identificados (quadros 1 e 2) quanto os efeitos prejudicantes que eles acarretam (quadro 3) são elementos constitutivos de lógicas de desconstrução e de descaracterização da identidade docente - que seguem, portanto, na contramão da profissionalização (TARDIF, 2013).

As pesquisas (quadros 1 e 2) também mostraram que há uma falta de suporte aos professores de $\mathrm{EaD}$, por parte dos agentes do campo da formação docente, o que configura um desafio referente à socialização docente. Vale notar que em nenhuma das publicações houve referência ao engajamento dos pares para desenvolvimento profissional de professores naquela modalidade de ensino. - A despeito de todas firmarem a necessidade de capacitação, na formação docente, para a produção de videoaulas.

Demais aspectos do trabalho docente puderam ser evidenciados (quadros 1 e 2): um deles, é a falta de espaços coletivos, nas IES, para apoio, partilha, colaboração, análise de práticas e reflexão dos professores sobre o ensino com videoaulas e outras práticas da docência a distância. Outro ponto passa pela ausência de participação do professor na construção de conhecimentos profissionais especializados para a modalidade. Também fica evidenciada a falta de envolvimento dos professores experientes com a formação de novos professores. Em complemento, inexiste iniciativas de composição de coletivos docentes, comunidades de práticas, comunidades de aprendizagem ou outras formas de organização que, no âmbito da profissionalidade, configurassem dispositivos de problematização e de reflexão crítica sobre o ensino para repercutir em conhecimentos, saberes docentes, cultura docente, identidade docente, aprendizagens e apoio para o enfrentamento de dificuldades e a busca de soluções inovadoras para problemas típicos da docência (GAUTHIER et al, 1998; NÓVOA, 2017; TARDIF, MOSCOSO, 2018).

No entanto, tais processos seriam altamente desejáveis para fomentar a profissionalidade, aproximando o trabalho da formação e possibilitando a construção de conhecimentos, os saberes docentes, o poder de decisão, a autonomia e o controle dos pares sobre a formação e o trabalho (TARDIF, 2013; NÓVOA 2009, 2011 e 2017). O movimento de olhar para as dúvidas, as dificuldades, os problemas, os dilemas e as incertezas dos professores torna-se, assim, necessário para refletir e intervir criticamente sobre a prática docente, reconstruindo sentidos e reinterpretando experiências, com vistas à construção da identidade de professor na contemporaneidade (CARDOSO, BATISTA, GRAÇA, 2016).

O processo de desenvolvimento profissional docente é favorecido quando os professores podem refletir e pesquisar sobre suas práticas para construir saberes e competências, através de processo amplo, dinâmico, flexível de etapas pessoais e coletivas de construção da profissão, na dialética entre indivíduo, grupo profissional e coletivo institucional (RAMALHO, NUÑES, GAUTHIER, 2004).

Reportamo-nos a Nóvoa (2009, 2011 e 2017), Gatti et al (2019) e Sarti (2019) para perguntar se o distanciamento entre a formação e a realidade de trabalho dos professores em EaD, não seria uma 
reedição, nesse momento de emergência de educação digital, do mesmo processo entre a universidade e a escola básica - que, na universitarização, envolveu a desvalorização simbólica dos professores e suas práticas com apagamento da cultura e da identidade docente, levando os professores das escolas a perderem seu "lugar próprio" na profissão e no processo de formação de novos professores?

Ou seja: estariam os professores de $\mathrm{EaD}$, ao produzirem as videoaulas sob orientações de comunicadores e moldes que não correspondem necessariamente aos da docência e, sem contar com apoio de seus pares, perdendo o seu "lugar próprio" na profissão e no processo de formação de novos professores?

Sarti (2019) contribui para lembrar que a profissionalização docente pressupõe que os professores exerçam controle estratégico dos processos de trabalho que realizam e que tenham papel ativo na tarefa de formar as próximas gerações docentes mediante o emprego de dispositivos que viabilizem a aproximação com a realidade do trabalho e a construção de uma identidade profissional em processo de socialização.

Seguindo o argumento, somos levados a supor que o trabalho de produção e prática docente de videoaulas em EaD, com as questões, as dificuldades e os problemas identificados no presente estudo e pela maneira como esses vêm sendo tratados pelas IES, acaba por colocar em risco a própria identidade profissional docente e atuar na contramão da construção da profissão, reforçando a desprofissionalização.

A EaD configura um cenário de ampliação do campo de trabalho docente com demandas específicas para o ser professor, a prática de ensino e a realidade da docência o qual, no entanto, vem se expandindo de modo apartado das pesquisas de doutoramento, dos debates, dos currículos, das disciplinas e das práticas formativas dos cursos de formação inicial e continuada de professores - inclusive naqueles da modalidade a distância. Sem preparo adequado para o ensino a distância os professores são alienados à própria formação (inicial, continuada e em serviço), uma vez que as condições e as rotinas do trabalho docente nessa modalidade de ensino representam uma faceta ainda a ser desvelada da docência em tempo de educação digital.

Considerando a necessidade da profissionalização docente, destacamos que as videoaulas configuram segmento docontexto da docência pouco explorado nas pesquisas sobre a prática docente. Dúvidas, dificuldades, problemas, dilemas e incertezas que os professores enfrentam no trabalho em EaD precisam ser identificados. Cabe identificar as soluções encontradas pelos professores, como também os saberes e os conhecimentos mobilizados e constituídos ou transformados nas práticas docentes. É preciso melhor conhecer as condições que interferem na (trans)formação da identidade profissional docente nessa modalidade. Aqui, formulamos alguns caminhos para ampliar as abordagens sobre formação, mediação tecnológica e profissão docente.

\section{CONSIDERAÇÕES FINAIS}

O artigo abordou as interfaces tecnologias e educação com enfoque para os desafios enfrentados pelo professor em uma faceta do trabalho docente na educação a distância, que é a produção e a prática de ensino com videoaulas.

Uma revisão do catálogo BR-CAPES-BTD permitiu a análise de pesquisas brasileiras que abordam questões, problemas e dificuldades enfrentados por professores e resultou na seleção de onze dissertações, mostrando que a temática é ainda pouco investigada.

A revisão mostrou que há precariedades formativas dos professores em elementos que seriam fundamentais para a produção de videoaulas: a linguagem audiovisual, a linguagem do professor (expressividade verbal, vocal e não verbal) e a integração dessas linguagens, assim como falhas na socialização profissional docente (falta de apoio dos professores e de integração do professor na equipe). Essas precariedades produzem conflitos, percepções e sentimentos negativos e desconfortos que podem instaurar processos de sofrimento e adoecimento de professores. Tais processos, se somados a elementos característicos do trabalho contemporâneo na $\mathrm{EaD}$ (ligados à fragmentação do trabalho, à flexibilização e à precarização) podem potencializar e agravar formas existentes de mal-estar docente já conhecidas no ensino presencial, vinculadas a antigas concepções de ensino (vocação e ofício). 
A revisão também mostrou a ausência de pesquisas que abordassem a temática na articulação dos campos epistêmicos da educação, da saúde e da comunicação - do que resulta a percepção de que a docência, na EaD, segue orientada por uma concepção de trabalho artesanal e técnico, identificado como ofício.

Com a análise de pesquisas sobre a produção de videoaulas em EaD, tensões e desafios da profissionalização docente foram identificados, enquanto também foi apontada a necessidade de uma formação de professores que permita consolidar a posição de cada pessoa como profissional e a própria posição da profissão (NÓVOA, 2017).

Os limites deste estudo, decorrentes dos recortes metodológicos (a escolha da base, os critérios de busca etc.), também demarcam ponto de partida para futuras pesquisas, com possibilidades para explorar outros recortes: as produções em periódicos; a docência no ensino remoto de modo geral, ainda mais considerando as experiências advindas do período pandêmico marcado pela urgência e desigualdade estrutural do acesso às tecnologias digitais. Como o período deste artigo se refere ao momento que antecede a crise global de saúde, novos contornos, comparações, devem ampliar o escopo de pesquisas, inclusive, no âmbito do doutoramento.

O ano de 2020 é emblemático para o campo educacional no que se refere: ao uso das tecnologias; ao engajamento dos professores em processos de reinvenção e de inovação das práticas de ensino; à visibilidade das limitações formativas e da ausência de suporte tecnológico ao professor. Período contemporâneo que evidenciou contradições sociais e diferenças entre escolas públicas e privadas e, também, entre os níveis de ensino, a configurarem múltiplas realidades e dificuldades enfrentadas por professores e alunos, com distintas percepções dos seus efeitos prejudicantes no bem-estar docente e discente, num contexto de diversidade de experiências com o processo de ensino-aprendizagem não presencial.

Este artigo contribui para pensar dimensões formativas das diversas realidades e condições do trabalho do professor na contemporaneidade. Isso envolve analisar criticamente a educação a distância sem desfazer da sua complexidade e sem desconsiderar as especificidades dessa modalidade de ensino e as necessidades ao trabalho do professor. É importante que os professores sejam subsidiados para o ensino com videoaulas e para a reflexão sobre as práticas docentes em EaD. Sobretudo, na formação docente (saberes docentes, cultura docente, identidade docente, socialização profissional) é que o professor deve buscar respostas para os dilemas, as questões, as dificuldades, os problemas, as necessidades do ensino o que não dispensa o diálogo interdisciplinar e a parceria com outras áreas.

Em tempos de educação digital, a produção de videoaulas é uma prática constituinte do trabalho docente que precisa ser analisada e compreendida (inclusive para estudo da socialização profissional)- e este artigo mostrou uma faceta dessa realidade da docência na EaD que tensiona a profissionalização e traz novos desafios para a formação docente, ainda mais quando as novas formas de mediação tecnológica trazem estruturas que modificam as condições de trabalho, a noção de presencialidade e as práticas de ensino.

\section{REFERÊNCIAS}

ABED. Censo EAD.br: Analytic report of distance learning in Brazil 2018. ABED - Associação Brasileira de Educação a Distância. Camila Rosa (tradutora). Curitiba: InterSaberes, 2019.

BALL, Stephen; BAILEY, Patrick; MENA, Paula. et al. A constituição da subjetividade docente no Brasil: um contexto global. Educação em Questão, Natal, v.46 n.32, p. 9-36, 2013.

BARBOSA, Luciane. A "performance" do professor da EAD: a implicação de elementos comunicacionais na teleaula. 2018. 87 f. Dissertação (Mestrado em Metodologias para o Ensino de Linguagens e suas Tecnologias) - Universidade Pitágoras Unopar, Londrina, 2018.

BARDIN, Laurance. Análise de conteúdo. Lisboa: Edições 70, 2010. 
BARROS, Maria das Graças; CARVALHO, Ana Beatriz. As concepções de interatividade nos ambientes virtuais de aprendizagem. In: SOUZA, Robson Pequeno; MOITA, Filomena; CARVALHO, Ana Beatriz. Tecnologias digitais na educação. EDUEPB, Campina Grande,p.201-232, 2011, p.201232.

BEHLAU, Mara; DRAGONE Maria Lúcia; NAGANO Lúcia. A voz que ensina - o professor e a comunicação oral em sala de aula. Rio de Janeiro: Revinter, 2004.

BRASIL. Decreto $\mathbf{n}^{\mathbf{0}} \mathbf{5 . 6 2 2}$, de 19 de dezembro de 2005. Regulamenta o art. 80 da Lei no 9.394, de 20 de dezembro de 1996, que estabelece as diretrizes e bases da educação nacional. Ministério da Educação. Diário Oficial da União, Brasília, DF; 20/12/2005, Seção 1, p.1.

BRASIL. Decreto $\mathbf{n}^{\circ} \mathbf{5 . 8 0 0}$, de 08 de junho de 2006. Dispõe sobre o Sistema Universidade Aberta do Brasil - UAB. Ministério da Educação. Diário Oficial da União, Brasília, DF, 09 de junho de 2006, p. 4.

BRASIL. Instituto Nacional de Estudos e Pesquisas Educacionais Anísio Teixeira (Inep). Censo da Educação Superior 2018: notas estatísticas. Brasília, 2019.

BRASIL. Portaria $\mathbf{n}^{\mathbf{0}} \mathbf{2 . 1 1 7}$, de 6de dezembro de 2019. Dispõe sobre a oferta de carga horária na modalidade de Ensino a Distância - EaD em cursos de graduação presenciais ofertados por Instituições de Educação Superior - IES pertencentes ao Sistema Federal de Ensino. Ministério da Educação. Diário Oficial da União, Brasília, DF, Publicado em: 11/12/2019, Edição: 239, Seção: 1, Página: 131.

BRASIL. Resolução CNE/CP n 2, de 20 de dezembro de 2019. Define as Diretrizes Curriculares Nacionais para a Formação Inicial de Professores para a Educação Básica e institui a Base Nacional Comum para a Formação Inicial de Professores da Educação Básica (BNC-Formação). Ministério da Educação. Diário Oficial da União, Brasília, DF, Publicado em: 10/2/2020, Seção 1, pp. 87 a 90.

BRASIL. Portaria $n^{\circ} 544$, de 16 de junho de 2020. Dispõe sobre a substituição das aulas presenciais por aulas em meios digitais, enquanto durar a situação de pandemia do novo coronavírus - Covid-19. Ministério da Educação. Diário Oficial da União, Brasília, DF, Publicado em: 17/06/2020; Edição: 114, Seção: 1, p.62.

CAMARGO, Celi. O processo de capacitação de professores para gravação de videoaula: uma experiência na EAD/UNIUBE. 105f. Dissertação. Mestrado em Educação; Universidade de Uberaba. Uberaba, 2012.

CAMPOS, Wellington O. O uso de videoaulas na educação corporativa - o caso Universidade Petrobras. 140 f. Dissertação. Mestrado em Ciência Tecnologia e Educação. Centro Federal de Educação Tecnológica Celso Suckow Fonseca. Rio de Janeiro, 2017.

CARDOSO, Maria Inês; BATISTA, Paula; GRAÇA, Amândio. A identidade do professor: desafios colocados pela globalização. Rev. Bras. Educação; v. 21 n. 65 abr.; 371-390; jun. 2016.

CECÍLIO, Sálua; REIS, Briana. Trabalho docente na era digital e saúde de professores universitários. Educação: Teoria e Prática, Rio Claro, vol. 26, n.52, p. 295-311, Mai-Ago, 2016.

COSTA, Belarmino Cesar. Estética da Violência, Jornalismo e Produção de Sentidos. Campinas / Piracicaba: Editora da Unicamp / Editora da Unimep, 2002.

ENGUITA, Mariano Fernandes. A ambiguidade da docência entre o profissionalismo e a proletarização. Teoria \& Educação. Dossiê: Interpretando o trabalho docente. Porto Alegre: 
Pannonica, n.4, p. 41-61, jan. 1991.

ESTEVE, Jose Manoel. O mal estar docente: a sala de aula e a saúde dos professores. Bauru: EDUSC, 1999.

ESTEVE, Jose Manoel. Mudanças sociais e função docente. In: NÓVOA, António. Profissão professor. 2.a. Ed. Porto: Porto Editora, reimpressão 2014, p. 93-124.

GATTI, Bernadette; BARRETO, Elba; ANDRÉ, Marli; ALMEIDA, Patrícia. Professores do Brasil: novos cenários de formação. Brasília: UNESCO, 2019.

GAUTHIER, Clermont; MARTINEAU, Stéphane; DESBIENS, Jean-François; MALO, Annie; SIMARD, Denis. Por uma teoria da pedagogia: pesquisas contemporâneas sobre o saber docente. Ijuí: Unijuí, 1998.

KYRILLOS, Leny (org). Expressividade: da teoria à prática. Rio de Janeiro: Revinter, 2005.

MACHADO, Wanessa. O professor na janela: representações sociais da videoaula para os professores do CEDERJ. 156 f. Dissertação. Mestrado Profissional em Educação, Gestão e Difusão em Biociências Instituição de Ensino; Universidade Federal do Rio de Janeiro. Rio de Janeiro, 2018.

MAUÉS, Olgaíses Cabral. Reformas internacionais da educação e formação de professores. In: SOUZA, Denise Trento; SARTI, Flávia Medeiros. Mercado de formação docente: constituição, funcionamento e dispositivos. Belo Horizonte: Fino Traço, 2014, p.37-70.

MAZZEU, Ian. Produção de videoaulas para EaD: contribuições para o diálogo com os educandos. Dissertação. Mestrado em Imagem e Som; Univ. Federal de São Carlos. São Carlos, 2012.

MEDEIROS, Solange. Estudos das preferências de alunos e professores sobre videoaulas para identificar requisitos de interface para ferramentas de produção. $125 \mathrm{f}$. Mestrado em Informática; Universidade Tecnológica Federal do Paraná. Cornélio Procópio, 2016.

MELO, Caio. Aparências valorizadas e contornos sublinhados: a construção do corpo e da imagem do docente televisivo na Fundação Universidade do Tocantins. Dissertação de Mestrado. Programa de Pós Graduação em Educação da Universidade Federal da Bahia. Salvador, 2009.

MILL, Daniel. Sobre o conceito de polidocência ou sobre a natureza do processo de trabalho pedagógico na educação a distância. In: MILL, Daniel; RIBEIRO, Luis Roberto; OLIVEIRA, Marcia. (Orgs.). Polidocência na Educação a Distância: múltiplos enfoques. São Carlos: EdUFSCar, 2014, p. 25-42.

MORAN, José Manuel. Aperfeiçoando os modelos de EAD existentes na formação de professores. Educação. Porto Alegre, v. 32, n. 3, p. 286-290, set./dez, 2009.

MOREIRA, Marcelo. A teleaula na EAD da Universidade Metodista de São Paulo: uma leitura da intersubjetividade presente nesta produção. Dissertação (Mestrado em Educação) Universidade Metodista de São Paulo, São Bernardo do Campo, 2010.

MOURA, Danielle. O trabalho docente e a produção de videoaulas na Educação a Distância. Dissertação. 100f. Programa de Pós-Graduação em Educação da Universidade Metodista de Piracicaba. Piracicaba, 2019. 
NÓVOA, António. O regresso dos professores. Pinhais: Melo, 2011.

NÓVOA, António. Para uma formação de professores construída dentro da profissão. In: NÓVOA, António. Professores: imagens do futuro presente. Lisboa: Educa, 2009, p. 25-46.

NÓVOA, António. Firmar a posição como professor, afirmar a profissão docente. Cadernos de Pesquisa v.47, n.166, p.1106-1133, 2017.

NÓVOA, António; ALVIM, Yara. Nothing is new, but everything has changed: A viewpoint on the future school. (UNESCO) Prospects (2020). https://doi.org/10.1007/s11125-020-09487-w

OLIVEIRA, Dalila Andrade. Os trabalhadores da educação e a construção política da profissão docente no Brasil. Educar em Revista, Curitiba, v.1, p. 17-35, 2010.

PECHULA, Marcia Reami; PENTEADO, Regina Zanella. A expressividade do professor em videoaulas - corpos e discursos dissonantes na formação em EaD. In: PECHULA, Marcia Reami; PENTEADO, Regina Zanella; DENARDO, Thierry (Orgs).Corpo - Mídia - Educação. Bragança Paulista: Margem da Palavra, 2018, p.119-140.

PENTEADO, Regina Zanella.; SOUZA NETO, Samuel. Mal-estar, sofrimento e adoecimento do professor: de narrativas do trabalho e da cultura docente à docência como profissão. Saúde Sociedade. São Paulo, v. 28, n. 1, p. 135-153, Mar. 2019.

PRIULI, Ricardo Medeiros. Uma aula na cabeça, uma câmera na mão: a transposição para videoaula na formação de professores na perspectiva da complexidade. Dissertação. Mestrado em Lingüística Aplicada e Estudos da Linguagem PUC- São Paulo. São Paulo, 2017.

RAMALHO, Betania, NUÑES, Isauro; GAUTHIER, Clermont. Formar o professor profissionalizar o ensino - perspectivas e desafios. Porto Alegre: Sulina, 2a ${ }^{\text {a }}$ ed., 2004.

RODRIGUES, Telma; ALMEIDA, Iara; DAL FORNO, Letícia. formação de professores para uso de TDICS em sala de aula: revisão sistemática das produções brasileiras. In: Anais do V CONGRESSO NACIONAL DE EDUCAÇÃO CONEDU - Olinda (PE) v. 1, 2018. Disponível em: https://www.editorarealize.com.br/revistas/conedu/anais.php Acesso em 28/08/2019.

SALDANHA, Luis Cláudio. A linguagem nas teleaulas: limites e possibilidades do diálogo pedagógico em EaD. Impulso, Piracicaba, v. 23, n. 57, p. 41-47, maio.set. 2013-a.

SALDANHA, Luis Cláudio. A teleaula em questão. Tear: Revista de Educação Ciência e Tecnologia, Canoas, v.2, n.2, p.1-13; 2013-b.

SANTOS, Gilberto Lacerda. Ensinar e aprender no meio virtual: rompendo paradigmas. Educação e Pesquisa, São Paulo, v.37, n.2, p. 307-320, 2011.

SARTI, Flávia Medeiros. O curso de pedagogia e a universitarização do magistério no Brasil: das disputas pela formação docente à sua desprofissionalização. Educação em Pesquisa, São Paulo, v. 45, p. 1-18, 2019.

SILVA JR, Geraldo. Contribuições didático-pedagógicas na produção de videoaulas: um olhar sobre a dinâmica do processo de ensino. 138 f. Dissertação. Mestrado em Tecnologia e Gestão na Educação a Distância; Universidade Federal Rural de Pernambuco. Recife, 2017. 
SOUZA Robson; MOITA, Filomena; CARVALHO, Ana Beatriz. Tecnologias digitais na educação. Campina Grande: EDUEPB, 2011.

TARDIF, Maurice. A profissionalização do ensino passados trinta anos: dois passos para a frente, três para trás. Educação \& Sociedade, Campinas, v.34, n.123, p.551-571, 2013.

TARDIF, Maurice.; MOSCOSO, Javier Nunez. A noção de "profissional reflexivo" na educação: atualidade, usos e limites. Cadernos de Pesquisa, v.48 n.168 p.388-411 abr./jun. 2018.

TEZONIN, Carlos Renato. EaD: A prática docente na produção de materiais audiovisuais. Revista Aprendizagem em EAD, v.8, p. 1-18; Taguatinga (DF); setembro, 2018.

VASCONCELOS, Humberto Borges. Material instrucional em educação a distância: a produção de videoaulas no curso de administração pública do Instituto Federal de Educação, Ciência e Tecnologia da Paraíba. Dissertação. 220f. Mestrado em Gestão em Organizações Aprendentes da Universidade Federal da Paraíba. João Pessoa, 2018.

VELOSO, Braian; MILL, Daniel. Precarização do trabalho docente na Educação a Distância: elementos para pensar a valorização da docência virtual. Educação em Foco, Juiz de Fora, v. 23, n. 1, p. 131-132, jan/abr, 2018.

VELOSO, Braian; MILL, Daniel. Produções científicas sobre a educação a distância e o trabalho docente nessa modalidade: um estudo bibliométrico. Trabalho \& Educação, v. 28, n. 1, p. 219-237, 21 fev. 2019.

O presente trabalho foi realizado com apoio da Coordenação de Aperfeiçoamento de Pessoal de Nível Superior - Brasil (CAPES) - Código de Financiamento 001. 